\title{
What's in a Number? Examining the Prognostic and Predictive Importance of Platelet Count in Patients With Essential Thrombocythemia
}

\author{
Andrew T. Kuykendall, MD, ${ }^{1}$ and Rami Komrokji, MD ${ }^{1}$
}

\begin{abstract}
Essential thrombocythemia (ET) is a myeloproliferative neoplasm characterized by clonal overproduction of platelets and an increased risk of thrombohemorrhagic complications. Patients are risk stratified by driver mutation, age, and thrombotic history and treated to reduce the risk of thrombotic and hemorrhagic events. The significance of platelet number as a risk factor or treatment goal is unclear. Despite the preponderance of data failing to demonstrate an association, there exists a pervasive belief that higher platelet counts correlate with an increased thrombotic risk. In fact, the association between thrombocytosis and bleeding is more clearly supported. Variability in regional consensus guidelines contributes to the uncertainty. This article reviews the data that shed light on the importance of platelet count in patients with ET.
\end{abstract}

J Natl Compr Canc Netw 2020;18(9):1279-1284 doi: $10.6004 /$ jnccn.2020.7595

${ }^{1} \mathrm{H}$. Lee Moffitt Cancer Center \& Research Institute, Tampa, Florida.
Essential thrombocythemia (ET) is a $B C R$ - $A B L 1$-negative myeloproliferative neoplasm (MPN) characterized by clonal thrombocytosis and proliferation of mature megakaryocytes within the bone marrow. ${ }^{1}$ Although ET is associated with a favorable prognosis, patients are at increased risk for both thrombotic and hemorrhagic complications that can impart significant morbidity and mortality. Over time, ET can progress to myelofibrosis or acute myeloid leukemia, occurrences that are unable to be prevented with current therapies. The treatment paradigm in ET aims to reduce the risk of thrombotic complications in higher-risk patients. Patients are stratified by age, prior thrombotic history, and driver mutation (ie, JAK2, MPL, CALR), with a corresponding risk category being assigned. ${ }^{2-4}$ Additional risk factors have been proposed but not universally incorporated into risk-stratification models, including cardiovascular risk factors, leukocytosis, and, perhaps most controversially, platelet count. ${ }^{5-11}$ Over the past 5 decades, there have been numerous attempts to characterize the impact of platelet count on clinical outcomes in patients with ET; however, because of inconsistent results and confounding factors, the debate continues.

In their seminal article that continues to influence practice patterns, Pearson and Wetherley-Mein ${ }^{12}$ failed to show a clear a correlation between platelet count and frequency of thrombotic events in a retrospective cohort of patients with polycythemia vera (PV), many of whom had wildly uncontrolled hematocrits by current standards. The relevant analysis used a univariate approach, making it difficult to draw strong conclusions regarding the independent influence of various risk factors. Regardless, noting that thrombotic events tended to occur more frequently at platelet counts in excess of $400 \times 10^{9} / \mathrm{L}$, the authors recommended the platelet count be controlled below this threshold. ${ }^{12}$ Twelve years later, Cortelazzo et $\mathrm{al}^{13}$ retrospectively analyzed 100 consecutive patients with ET (by Polycythemia Vera Study Group [PVSG] criteria) and failed to find a relationship between 
platelet number and frequency of thrombotic events. In light of this, they performed a subgroup analysis of 74 patients treated with intermittent busulfan and found an increased frequency of thrombotic events in patients considered to be short-remitters, defined as those who spent $<70 \%$ of follow-up time with platelet counts $<600 \times 10^{9} / \mathrm{L}$. Short- and long-remitters did not differ by baseline platelet count, age, sex, or time to achieve remission, suggesting this label may be a surrogate for disease intensity. ${ }^{13}$ Studies from Buxhofer-Ausch et al ${ }^{14}$ and Schwarz et $\mathrm{al}^{15}$ also found links between thrombocytosis and thrombosis risk by investigating registry data from anagrelide-treated patients with ET or myeloproliferative disorders and thrombocytosis (MPD-T), respectively. In the former study, the authors compared 34 patients with ET who experienced a major thrombotic event (MTE) with 586 who had not. Although baseline platelet count was not different between the groups, the median platelet count preceding an MTE was significantly higher than the median platelet count throughout follow-up in patients without an MTE. ${ }^{14}$ Similarly, in a study of 1,179 patients with MPD-T, Schwarz et al ${ }^{15}$ found that the platelet count preceding a thrombotic event (not exceeding 100 days) was significantly higher than the median platelet count during follow-up of patients without a thrombotic event. Although intriguing, these 2 studies fail to demonstrate a clear cause-and-effect relationship between thrombosis and platelet number. Platelet elevation in the perithrombotic period may reflect the role of platelets as an acute-phase reactant; after all, thrombotic events are an inherently inflammatory event. ${ }^{16,17}$ Moreover, neither study correlated platelet count at diagnosis and future thrombosis, with the latter study noting an inverse relationship between platelet count at diagnosis and history of major thrombosis. ${ }^{15}$ Notably, both studies focused on anagrelide-treated patients, suggesting the significance of thrombocytosis may be specific to this group. This, however, runs counter to the findings of Hernandez-Boluda et $\mathrm{al}^{18}$ who showed that thrombosis and hemorrhage were independent of anagrelide response, per European LeukemiaNet (ELN) response criteria.

Contrary to the conclusions drawn from the aforementioned studies, numerous investigations have failed to link an elevated platelet count to increased thrombotic risk. Carobbio et $\mathrm{al}^{7}$ reviewed 657 patients with ET (by PVSG criteria) and assessed the role of platelet count by quartile, finding no correlation with thrombosis. This study included both high- and low-risk patients with 59\% receiving cytoreductive therapy at study entry. ${ }^{7}$ A subsequent international collaboration using the WHO definition for ET analyzed 891 patients to assess risk factors for arterial and venous thrombosis. Using multivariate analysis, this study showed that a platelet count exceeding $1,000 \times 10^{9} / \mathrm{L}$ was associated with a decreased incidence of arterial thrombosis but had no impact on venous thrombosis. The correlation between extreme thrombocytosis and a reduced risk for arterial thrombosis remained after restricting the analysis to patients with JAK2V617F-mutated disease. Notably, this study did not find a correlation between extreme thrombocytosis and major bleeding. ${ }^{19}$

In an effort to minimize the potential confounding impact of heterogeneous cytoreductive approaches in retrospective analyses, Alvarez-Larrán et $\mathrm{al}^{20}$ analyzed 300 low-risk patients with ET who were not treated with cytoreductive therapy. The primary aim of this study was to assess the role of antiplatelet therapy. They found antiplatelet therapy to be associated with a decreased incidence of venous thrombosis in patients with JAK2 V617F-mutated disease and a decreased risk of arterial thrombosis in patients with cardiovascular risk factors. An increased risk of major bleeding was noted in patients with platelet counts $>1,000 \times 10^{9} / \mathrm{L}$ who received antiplatelet therapy. Multivariate analysis of risk factors for thrombosis and hemorrhage using a platelet threshold of $800 \times 10^{9} / \mathrm{L}$ did not show a significant correlation between thrombocytosis and either arterial or venous thrombosis, instead showing a significant correlation between thrombocytosis and risk of major bleeding while controlling for antiplatelet therapy, leukocyte count, hemoglobin level, cardiovascular risk factors, sex, and age. ${ }^{20} \mathrm{~A}$ subsequent analysis of low-risk patients with ET incorporated CALR mutation status, showing the correlation between extreme thrombocytosis $\left(>1,000 \times 10^{9} / \mathrm{L}\right)$ and major bleeding to be more pronounced in patients with JAK2mutated disease, further suggesting the prognostic impact of platelet number may vary by driver mutation. ${ }^{21}$ Gugliotta et $\mathrm{al}^{22}$ used a different strategy to minimize the confounding impact of heterogeneous treatment strategies. They correlated blood counts at diagnosis with thrombotic events that preceded diagnosis and treatment. Among 977 patients with MPD-T, there was a clear inverse relationship between platelet count at diagnosis and history of a prior thrombotic event. ${ }^{22}$ This is consistent with the findings by Schwarz et $\mathrm{al}^{15}$ in their analysis of patients with MPD-T treated with anagrelide. Taken together, these studies suggest that outside the context of cytoreductive therapy, an increased platelet count is not associated with an increased thrombotic risk. On the contrary, it may be associated with a decreased incidence of thrombosis and an increased hemorrhagic risk, although the latter may be limited to patients with $J A K 2$ V617F-mutated disease and may be exacerbated by antiaggregation therapy. In addition, the antithrombotic benefit of antiplatelet therapy in JAK2-mutated disease implicates the qualitative importance of platelets in the pathogenesis of MPN-associated thrombosis.

Analyses of 4 large, prospectively enrolling MPN studies (the European Collaboration on Low-dose Aspirin in 
Polycythemia Vera prospective study [ECLAP], Primary Thrombocythaemia-1 trial [PT-1], PVSG-01 study, and Evaluation of Anagrelide Efficacy and Long-term Safety [EXELS] study) have failed to demonstrate an association between platelet count and thrombotic risk. ${ }^{23-25} \mathrm{Al}-$ though the ECLAP and PVSG-01 studies were limited to patients with PV, their results are significant because PV represents a molecularly homogenous MPN population with disease driven by a JAK2 mutation. Interestingly, the ECLAP study showed a relationship between high platelet counts and a lower rate of progression to acute leukemia and myelofibrosis, a relationship that has not been strongly supported otherwise. ${ }^{23}$ The PT-1 study analyzed 776 patients with ET and used a cubic splines approach to eliminate the inherent bias of viewing the impact of platelet count as linear or discontinuous at a specific cutpoint. There was no significant association between platelet counts at diagnosis and future risk of thrombosis, major hemorrhage, or disease transformation. Platelet counts during follow-up, although not associated with thrombosis, were associated with major hemorrhage at both low and high values. ${ }^{24}$ Similar findings were seen in the EXELS study that followed 3,649 patients with ET receiving cytoreductive therapy. Extreme thrombocytosis was associated with major hemorrhage, but no correlation was found between initial platelet count and arterial or venous thrombosis. ${ }^{26}$

The protective benefit of cytoreductive agents in ET has been attributed to the ability of these agents to reduce platelet count. In a randomized controlled trial, hydroxyurea reduced the risk of thrombotic events in 114 patients with PVSG-defined ET. In this study, patients were treated with a goal of maintaining platelet counts $<600 \times 10^{9} /$ L. $^{27}$ Along the same lines, Alvarez-Larrán et $\mathrm{al}^{28}$ found that patients with who did not achieve a platelet response to hydroxyurea experienced more thrombotic and bleeding events. Although these data support the protective benefit of hydroxyurea, especially in patients with platelet control, it is likely that the agent exerts its influence via multiple mechanisms. In addition to providing cytoreduction, hydroxyurea reduces neutrophil activity, decreases expression of endothelial adhesion molecules, and induces nitric oxide generation. ${ }^{29-33}$ The findings of Alvarez-Larran et al ${ }^{28}$ seem to mirror the concept of short-remitters by Cortelazzo et al, ${ }^{13}$ wherein a short-lived or lack of platelet response represents higher-risk disease.

Two randomized comparisons of hydroxyurea and anagrelide in ET provide further information regarding the impact of cytoreduction. In the first, high-risk PVSGdefined patients with ET were randomly assigned to either hydroxyurea or anagrelide with a goal platelet count of $<400 \times 10^{9} / \mathrm{L}$. Despite comparable platelet control, hydroxyurea-treated patients experienced fewer thrombohemorrhagic events compared with anagrelide-treated patients, indicating that platelet count control is, at best, a part of the story. ${ }^{34}$ The subsequent ANAHYDRET study demonstrated noninferiority between hydroxyurea and anagrelide after applying the more stringent WHO diagnostic criteria, suggesting that a subset of patients not captured by the WHO definition were responsible for the benefit attributed to hydroxyurea in the former study. ${ }^{35}$

The variability in conclusions drawn from these studies is reflected in the differing guidelines issued by cooperative groups. NCCN and ELN do not consider thrombocytosis a risk factor for thrombosis, while noting that severe thrombocytosis is a risk factor for hemorrhage due to its association with acquired von Willebrand disease (vWD). ${ }^{36,37}$ Conversely, the Central European Myeloproliferative Neoplasms Organization (CEMPO) considers platelet count a thrombotic risk factor and uses quantitative thresholds to guide treatment goals.

At our center, we stratify patients by the revised International Prognostic Score of Thrombosis in ET (IPSET-Thrombosis) that incorporates 3 variables: age $>60$, prior thrombotic event, and JAK2 V617F mutation. ${ }^{3,4}$ We encourage aggressive control of cardiovascular risk factors in all patients and antiplatelet therapy with lowdose aspirin in most patients while making exceptions for those with acquired vWD, with significant bleeding history, or at very low risk for thrombosis. We recommend cytoreductive therapy for all patients with high-risk disease and defer cytoreductive therapy in patients with very low- and low-risk disease. For intermediate-risk patients, we favor cytoreductive therapy, but this decision is shared between the physician and a well-informed patient. In patients receiving cytoreductive therapy, we do not recommend a specific platelet goal; rather, we aim to optimize the balance between hematologic control and the patient's overall quality of life. For patients with a bleeding history or platelet count $>1,000 \times 10^{9} / \mathrm{L}$, we obtain a ristocetin cofactor assay to assess for acquired vWD. In patients with a bleeding history and low vWF activity, we recommend cytoreductive therapy with a goal of eliminating bleeding events and normalizing vWF activity. In patients with decreased vWF activity associated with extreme thrombocytosis who lack a significant bleeding history, we favor cytoreductive therapy and will monitor vWF activity to gauge response. In patients with extreme thrombocytosis, normal vWF activity, and no history of either major or minor bleeding, we do not routinely recommend cytoreductive therapy; however, this is another situation in which shared decision-making is vital.

Broadly speaking, the lack of consensus regarding the impact of platelet count in ET suggests this is a complex relationship that is difficult to evaluate specifically (Table 1). Issues related to study design, patient population, data interpretation, and an increasing molecular understanding of ET have confounded the ability 


\section{Table 1. Studies Assessing Relationship Between Platelet Count and Clinical Outcomes in MPNs}

\begin{tabular}{|c|c|c|c|c|c|}
\hline & Study Design & $\begin{array}{l}\text { Patient } \\
\text { Population (n) }\end{array}$ & Analysis & $\begin{array}{l}\text { Specific Platelet-Related } \\
\text { Association Assessed }\end{array}$ & Findings \\
\hline $\begin{array}{l}\text { Pearson \& } \\
\text { Wetherley- } \\
\text { Mein, }{ }^{12} 1978\end{array}$ & Retrospective & PV (69) & Univariate & $\begin{array}{l}\text { Incidence of thrombotic event with } \\
\text { platelet count at time of event }\end{array}$ & No significant correlation $(P>.2)$ \\
\hline $\begin{array}{l}\text { Cortelazzo et al, }{ }^{13} \\
1990\end{array}$ & Retrospective & ET (100) & Univariate & $\begin{array}{l}\text { Frequency of thrombotic event with } \\
\text { platelet count at time of event }\end{array}$ & No clear relationship \\
\hline $\begin{array}{l}\text { Cortelazzo et al, }{ }^{13} \\
1990\end{array}$ & $\begin{array}{l}\text { Retrospective, } \\
\text { subgroup analysis }\end{array}$ & $\begin{array}{l}\text { ET treated with } \\
\text { busulfan (74) }\end{array}$ & Univariate & $\begin{array}{l}\text { Frequency of thrombotic events and } \\
\text { time spent with platelet count } \\
<600 \times 10^{9} / \mathrm{L} \\
\text { Short-remitter defined as spending } \\
<70 \% \text { of follow-up with platelet } \\
\text { count }<600 \times 10^{9} / \mathrm{L} \text { despite busulfan } \\
\text { treatment }\end{array}$ & $\begin{array}{l}\text { Short-remitters had higher incidence } \\
\text { of thrombotic complications } \\
(P<.0025)\end{array}$ \\
\hline $\begin{array}{l}\text { Carobbio et al, } \\
2008\end{array}$ & Retrospective & ET (657) & Multivariate & $\begin{array}{l}\text { Thrombotic event with baseline } \\
\text { platelet count at diagnosis by } \\
\text { quartile (quartiles bound at upper } \\
\text { limit by } 650 \times 10^{\circ} / \mathrm{L}, 772 \times 10^{\circ} / \mathrm{L} \text {, } \\
977 \times 10^{\circ} / \mathrm{L} \text {, and } 2,269 \times 10^{\circ} / \mathrm{L} \text { ) }\end{array}$ & No significant correlation \\
\hline $\begin{array}{l}\text { Carobbio et al, }{ }^{19} \\
2011\end{array}$ & Retrospective & ET (891) & Multivariate & $\begin{array}{l}\text { Major thrombotic event, arterial, } \\
\text { venous thrombosis, major } \\
\text { hemorrhage with platelet count at } \\
\text { diagnosis (cutpoint } 1,000 \times 10^{9} / \mathrm{L} \text { ) }\end{array}$ & $\begin{array}{l}\text { Decreased incidence of major } \\
\text { thrombosis }(P=.009) \text { and arterial } \\
\text { thrombosis }(P=.007) \text { with platelet } \\
\text { count }>1,000 \times 10^{9} / \mathrm{L} \\
\text { No correlation with venous } \\
\text { thrombosis or hemorrhage }\end{array}$ \\
\hline $\begin{array}{l}\text { Alvarez-Larrán } \\
\text { et al, }{ }^{20} 2010\end{array}$ & Retrospective & Low-risk ET (300) & Multivariate & $\begin{array}{l}\text { Major thrombotic event, arterial, } \\
\text { venous thrombosis, major bleeding } \\
\text { with platelet count at presentation } \\
\text { (cutpoint } 800 \times 10^{\circ} / \mathrm{L} \text { ) }\end{array}$ & $\begin{array}{l}\text { Increased incidence of major } \\
\text { bleeding }(P=.01) \text { with platelet count } \\
>800 \times 10^{9} / \mathrm{L} \\
\text { No correlation with total, arterial, or } \\
\text { venous thromboses }\end{array}$ \\
\hline $\begin{array}{l}\text { Alvarez-Larrán } \\
\text { et } a_{1}{ }^{21} 2016\end{array}$ & Retrospective & $\begin{array}{l}\text { Low-risk ET ( } 433) \\
\text { stratified by driver } \\
\text { mutation }\end{array}$ & $\begin{array}{l}\text { Multivariate } \\
\text { with propensity } \\
\text { scoring }\end{array}$ & $\begin{array}{l}\text { Major bleed with platelet count at } \\
\text { presentation (cut-point } 1,000 \times 10^{\circ} / \mathrm{L} \text { ) } \\
\text { in the presence of antiplatelet } \\
\text { therapy and stratified by JAK2/CALR } \\
\text { mutation status }\end{array}$ & $\begin{array}{l}\text { In JAK2-mutated patients, platelet } \\
\text { count }>1,000 \times 10^{\circ} / L \text { correlated with } \\
\text { increased bleeding risk }(P=.002) \text {.No } \\
\text { significant correlation between } \\
\text { platelet count }>1,000 \times 10^{\circ} / L \text { and } \\
\text { bleeding in } C A L R \text {-mutated patients } \\
(P=.1)\end{array}$ \\
\hline $\begin{array}{l}\text { Gugliotta et al, } \\
2016\end{array}$ & Retrospective & $\begin{array}{l}\text { MPN with } \\
\text { thrombocytosis } \\
\text { (977) }\end{array}$ & Multivariate & $\begin{array}{l}\text { Major thrombotic event (ie, before } \\
\text { diagnosis/treatment) with platelet } \\
\text { count at diagnosis (cutpoint of } \\
700 \times 10^{9} / \mathrm{L} \text { and } 1,000 \times 10^{9} / \mathrm{L} \text { ) }\end{array}$ & $\begin{array}{l}\text { Decreased incidence of prior } \\
\text { thrombosis with higher platelet } \\
\text { count using both } 700 \times 10^{\circ} / \mathrm{L} \\
(P<.001) \text { and } 1,000 \times 10^{\circ} / \mathrm{L}(P=.022) \\
\text { as cutpoint }\end{array}$ \\
\hline $\begin{array}{l}\text { Schwarz et al, }{ }^{15} \\
2016\end{array}$ & $\begin{array}{l}\text { Retrospective } \\
\text { analysis of } \\
\text { prospectively } \\
\text { enrolled registry }\end{array}$ & $\begin{array}{l}\text { MPN with } \\
\text { thrombocytosis } \\
\text { treated with } \\
\text { anagrelide }(1,179)\end{array}$ & Univariate & $\begin{array}{l}\text { All thrombotic events, major } \\
\text { thrombotic events, arterial, venous } \\
\text { thrombosis (historically and/or } \\
\text { during follow-up) with platelet count } \\
\text { at diagnosis }\end{array}$ & $\begin{array}{l}\text { Median platelet count significantly } \\
\text { higher in patients without a history of } \\
\text { major thrombosis }(P=.001) \\
\text { No difference in platelet count at } \\
\text { diagnosis and incidence of } \\
\text { thrombosis during follow-up }\end{array}$ \\
\hline $\begin{array}{l}\text { Schwarz et al, }{ }^{15} \\
2016\end{array}$ & $\begin{array}{l}\text { Retrospective } \\
\text { analysis of } \\
\text { prospectively } \\
\text { enrolled registry }\end{array}$ & $\begin{array}{l}\text { MPN with } \\
\text { thrombocytosis } \\
\text { treated with } \\
\text { anagrelide }(1,179)\end{array}$ & Univariate & $\begin{array}{l}\text { All thrombotic events, arterial, } \\
\text { microcirculatory, venous thrombosis } \\
\text { with last platelet count before } \\
\text { thrombotic event (not exceeding } \\
100 \mathrm{~d} \text { ) }\end{array}$ & $\begin{array}{l}\text { Median platelet count preceding } \\
\text { thrombotic event was higher than } \\
\text { median platelet count in patients } \\
\text { who did not experience a thrombosis } \\
(P=.001)\end{array}$ \\
\hline $\begin{array}{l}\text { Di Nisio et al, } \\
2007\end{array}$ & $\begin{array}{l}\text { Retrospective } \\
\text { analysis of } \\
\text { prospectively } \\
\text { enrolled study }\end{array}$ & PV $(1,638)$ & $\begin{array}{l}\text { Multivariate } \\
\text { time- } \\
\text { dependent }\end{array}$ & $\begin{array}{l}\text { Mortality, major thrombotic events, } \\
\text { total thrombotic events, disease } \\
\text { transformation with platelet count } \\
\text { preceding the event (for thrombotic } \\
\text { events) and at baseline (for mortality } \\
\text { and disease transformation) }\end{array}$ & $\begin{array}{l}\text { No correlation between platelet } \\
\text { count and thrombosis or mortality } \\
\text { Higher platelet count correlated with } \\
\text { lower progression rate to acute } \\
\text { leukemia/myelofibrosis }\end{array}$ \\
\hline Berk et al, ${ }^{25} 1995$ & $\begin{array}{l}\text { Retrospective } \\
\text { analysis of } \\
\text { prospectively } \\
\text { enrolled study }\end{array}$ & PV (431) & Univariate & $\begin{array}{l}\text { Thrombotic events with platelet } \\
\text { count before event }\end{array}$ & $\begin{array}{l}\text { No correlation between platelet } \\
\text { count preceding event and risk of } \\
\text { thrombosis }\end{array}$ \\
\hline
\end{tabular}




\begin{tabular}{|c|c|c|c|c|c|}
\hline & Study Design & $\begin{array}{l}\text { Patient } \\
\text { Population (n) }\end{array}$ & Analysis & $\begin{array}{l}\text { Specific Platelet-Related } \\
\text { Association Assessed }\end{array}$ & Findings \\
\hline $\begin{array}{l}\text { Campbell et al, }{ }^{24} \\
2012\end{array}$ & $\begin{array}{l}\text { Retrospective } \\
\text { analysis of } \\
\text { prospectively } \\
\text { enrolled study }\end{array}$ & ET (776) & $\begin{array}{l}\text { Multivariate } \\
\text { using cubic } \\
\text { splines basis }\end{array}$ & $\begin{array}{l}\text { Thrombotic events, major } \\
\text { hemorrhage, disease transformation } \\
\text { with platelet count at diagnosis and } \\
\text { during follow-up ( } 60 \mathrm{~d} \text { preceding a } \\
\text { vascular complication) }\end{array}$ & $\begin{array}{l}\text { Major hemorrhage correlated with } \\
\text { high and low platelet counts } \\
(P=.0005) \text { during follow-up } \\
\text { No correlation between platelet } \\
\text { count at diagnosis and future risk of } \\
\text { thrombosis, hemorrhage, or disease } \\
\text { transformation }\end{array}$ \\
\hline $\begin{array}{l}\text { Birgegård et al, }{ }^{26} \\
2018\end{array}$ & $\begin{array}{l}\text { Retrospective } \\
\text { analysis of } \\
\text { prospectively } \\
\text { enrolled study }\end{array}$ & ET $(3,649)$ & Multivariate & $\begin{array}{l}\text { Major thrombotic events, arterial } \\
\text { thrombotic events, venous } \\
\text { thrombotic events, major } \\
\text { hemorrhagic events, } \\
\text { thrombohemorrhagic events, } \\
\text { transformation to myelofibrosis and } \\
\text { acute leukemia/myelodysplastic } \\
\text { syndrome }\end{array}$ & $\begin{array}{l}\text { Initial platelet count }>1,000 \times 10^{9} \\
\text { correlated with increased risk of } \\
\text { major hemorrhagic events } \\
\text { Higher baseline platelet count } \\
\text { correlated with increased risk of } \\
\text { transformation to myelofibrosis }\end{array}$ \\
\hline
\end{tabular}

Abbreviations: ET, essential thrombocythemia; MPN, myeloproliferative neoplasm; PV, polycythemia vera.

to fully define the relationship. Relevant analyses are retrospective in nature, and thus have limited applicability and a high potential for bias. Frequently, studies include patients receiving disparate treatments based on the prevailing guidelines, impairing the ability to analyze the prognostic significance of hematologic values that are invariably impacted by cytoreductive therapy. Platelet number is variably treated as continuous or dichotomous and analyzed at differing time points. Inconsistent patient populations and evolving diagnostic criteria limit the ability to compare results across studies. The emerging molecular understanding of ET further challenges the interpretation of historical studies that completely or partially lack this vital information. Beyond methodologic inconsistency, studies demonstrating associations often conflate correlation with causation. With myriad confounding variables and caveats clouding an already complex pathologic process, it becomes nearly impossible to draw clear, consistent conclusions from the available data. Perhaps most importantly, the question itself, although ostensibly straightforward, inherently underestimates the complexity of the disease. To accept or refute that the platelet count in ET has a clear relationship with thrombosis (or other disease-related endpoints) is to ignore, or at least minimize, that the platelet count can be highly influenced by both disease- and nondisease-related factors while trivializing the array of additional factors that contribute to thrombosis formation.
Ultimately, the debate surrounding the independent importance of platelet count in ET is an indictment of our existing treatment options. Disease-modifying agents with the ability to induce morphologic and molecular remissions while reducing the inflammatory burden and disease-associated thrombotic risk would render this question academic. Although clinical trials in ET have been historically challenging, novel agents with potentially disease-modifying activity are making their way to the clinic. Ropeginterferon alfa-2b, which has shown impressive activity in patients with $\mathrm{PV}$, will be evaluated in an upcoming trial of patients with ET who are resistant or intolerant to hydroxyurea (ClinicalTrials. gov identifier: NCT04285086). In addition, a phase II study of bomedemstat (IMG-7289), a lysine-specific demethylase 1 (LSD1) inhibitor that specifically targets megakaryocyte maturation, will soon begin enrolling patients with ET (NCT04254978). As novel agents enter the clinic, we must look beyond blood count control and thrombosis prevention, instead focusing on disease modification, stem cell eradication, and molecular remission.

Submitted January 21, 2020; accepted for publication May 21, 2020.

Disclosures: The authors have disclosed that they have no financial interests, arrangements, or affiliations with the manufacturers of any products discussed in this article or their competitors

Correspondence: Andrew T. Kuykendall, MD, H. Lee Moffitt Cancer Center \& Research Institute, 12902 USF Magnolia Drive, COB 7th Floor, Tampa, FL 33612. Email: Andrew.Kuykendall@moffitt.org

\section{References}

1. Arber DA, Orazi A, Hasserjian R, et al. The 2016 revision to the World Health Organization classification of myeloid neoplasms and acute leukemia. Blood 2016;127:2391-2405.

2. Tefferi A, Barbui T. Polycythemia vera and essential thrombocythemia: 2019 update on diagnosis, risk-stratification and management. Am J Hematol 2019;94:133-143.

3. Barbui $T$, Vannucchi AM, Buxhofer-Ausch $V$, et al. Practice-relevant revision of IPSET-thrombosis based on 1019 patients with WHO-defined essential thrombocythemia. Blood Cancer J 2015;5:e369.

4. Haider M, Gangat N, Lasho T, et al. Validation of the revised International Prognostic Score of Thrombosis for Essential Thrombocythemia (IPSETthrombosis) in 585 Mayo Clinic patients. Am J Hematol 2016;91:390-394. 
5. Lekovic D, Gotic M, Milic N, et al. The importance of cardiovascular risk factors for thrombosis prediction in patients with essential thrombocythemia. Med Oncol 2014;31:231.

6. Carobbio A, Finazzi G, Guerini V, et al. Leukocytosis is a risk factor for thrombosis in essential thrombocythemia: interaction with treatment, standard risk factors, and Jak2 mutation status. Blood 2007;109:2310-2313.

7. Carobbio A, Antonioli E, Guglielmelli P, et al. Leukocytosis and risk stratification assessment in essential thrombocythemia. J Clin Oncol 2008; 26:2732-2736.

8. Gangat N, Wolanskyj AP, Schwager SM, et al. Leukocytosis at diagnosis and the risk of subsequent thrombosis in patients with low-risk essential thrombocythemia and polycythemia vera. Cancer 2009;115:5740-5745.

9. Girodon F, Dutrillaux F, Broséus J, et al. Leukocytosis is associated with poor survival but not with increased risk of thrombosis in essential thrombocythemia: a population-based study of 311 patients. Leukemia 2010;24:900-903.

10. De Stefano V, Za T, Rossi E, et al. Leukocytosis is a risk factor for recurrent arterial thrombosis in young patients with polycythemia vera and essential thrombocythemia. Am J Hematol 2010;85:97-100.

11. Carobbio A, Ferrari A, Masciulli A, et al. Leukocytosis and thrombosis in essential thrombocythemia and polycythemia vera: a systematic review and meta-analysis. Blood Adv 2019;3:1729-1737.

12. Pearson TC, Wetherley-Mein G. Vascular occlusive episodes and venous haematocrit in primary proliferative polycythaemia. Lancet 1978;2:1219-1222.

13. Cortelazzo S, Viero P, Finazzi G, et al. Incidence and risk factors for thrombotic complications in a historical cohort of 100 patients with essential thrombocythemia. J Clin Oncol 1990;8:556-562.

14. Buxhofer-Ausch V, Steurer M, Sormann S, et al. Influence of platelet and white blood cell counts on major thrombosis-analysis from a patient registry in essential thrombocythemia. Eur J Haematol 2016;97:511-516.

15. Schwarz J, Ovesná P, Černá O, et al. Thrombosis in thrombocythemic Phmyeloproliferations is associated with higher platelet count prior to the event: results of analyses of prothrombotic risk factors from a registry of patients treated with anagrelide. Eur J Haematol 2016;96:98-106.

16. Fox EA, Kahn SR. The relationship between inflammation and venous thrombosis. A systematic review of clinical studies. Thromb Haemost 2005;94:362-365.

17. Roumen-Klappe EM, den Heijer M, van Uum SH, et al. Inflammatory response in the acute phase of deep vein thrombosis. J Vasc Surg 2002; 35:701-706

18. Hernandez-Boluda JC, Pereira A, Cervantes F, et al. Clinical evaluation of the European LeukemiaNet response criteria in patients with essential thrombocythemia treated with anagrelide. Ann Hematol 2013;92:771-775.

19. Carobbio A, Thiele J, Passamonti F, et al. Risk factors for arterial and venous thrombosis in WHO-defined essential thrombocythemia: an international study of 891 patients. Blood 2011;117:5857-5859.

20. Alvarez-Larrán A, Cervantes F, Pereira A, et al. Observation versus antiplatelet therapy as primary prophylaxis for thrombosis in low-risk essentia thrombocythemia. Blood 2010;116:1205-1210, quiz 1387.

21. Alvarez-Larrán A, Pereira A, Guglielmelli P, et al. Antiplatelet therapy versus observation in low-risk essential thrombocythemia with a CALR mutation. Haematologica 2016;101:926-931.
22. Gugliotta L, lurlo A, Gugliotta G, et al. Unbiased pro-thrombotic features at diagnosis in 977 thrombocythemic patients with Philadelphia-negative chronic myeloproliferative neoplasms. Leuk Res 2016;46:18-25.

23. Di Nisio M, Barbui T, Di Gennaro $L$, et al. The haematocrit and platelet target in polycythemia vera. Br J Haematol 2007;136:249-259.

24. Campbell PJ, MacLean C, Beer PA, et al. Correlation of blood counts with vascular complications in essential thrombocythemia: analysis of the prospective PT1 cohort. Blood 2012;120:1409-1411.

25. Berk PD, Wasserman LR, Fruchtman SM, Goldberg JD. Treatment of polycythemia vera: a summary of clinical trials conducted by the Polycythemia Vera Study Group. In: Wasserman LR, Berk PD, Berlin NI. Polycythemia Vera and the Myeloproliferative Disorders. Philadelphia, PA: W.B. Saunders Company; 1995:166-194.

26. Birgegård G, Besses C, Griesshammer M, et al. Treatment of essential thrombocythemia in Europe: a prospective long-term observational study of 3649 high-risk patients in the Evaluation of Anagrelide Efficacy and Long-term Safety study. Haematologica 2018;103:51-60.

27. Cortelazzo S, Finazzi G, Ruggeri M, et al. Hydroxyurea for patients with essential thrombocythemia and a high risk of thrombosis. N Engl J Med 1995;332:1132-1136.

28. Alvarez-Larrán A, Pereira A, Cervantes F, et al. Assessment and prognostic value of the European LeukemiaNet criteria for clinicohematologic response, resistance, and intolerance to hydroxyurea in polycythemia vera. Blood 2012;119:1363-1369.

29. Adragna NC, Fonseca P, Lauf PK. Hydroxyurea affects cell morphology, cation transport, and red blood cell adhesion in cultured vascular endothelial cells. Blood 1994;83:553-560.

30. Gladwin MT, Shelhamer JH, Ognibene FP, et al. Nitric oxide donor properties of hydroxyurea in patients with sickle cell disease. $\mathrm{Br} \mathrm{J}$ Haematol 2002;116:436-444.

31. Cokic VP, Beleslin-Cokic BB, Tomic M, et al. Hydroxyurea induces the eNOS-cGMP pathway in endothelial cells. Blood 2006;108:184-191.

32. Lockwood SY, Erkal JL, Spence DM. Endothelium-derived nitric oxide production is increased by ATP released from red blood cells incubated with hydroxyurea. Nitric Oxide 2014;38:1-7

33. Gumiero D, Di Gennaro L, Nicolazzi MA, et al. Hydroxyurea-mediated release of nitric oxide in myeloproliferative neoplasms patients: effects on platelet-leukocyte interaction. J Clin Pharmacol 2015;55:1125-1130.

34. Harrison CN, Campbell PJ, Buck G, et al. Hydroxyurea compared with anagrelide in high-risk essential thrombocythemia. N Engl J Med 2005; 353:33-45.

35. Gisslinger $\mathrm{H}$, Gotic $\mathrm{M}$, Holowiecki J, et al. Anagrelide compared with hydroxyurea in WHO-classified essential thrombocythemia: the ANAHYDRET study, a randomized controlled trial. Blood 2013;121: 1720-1728.

36. Barbui T, Tefferi A, Vannucchi AM, et al. Philadelphia chromosomenegative classical myeloproliferative neoplasms: revised management recommendations from European LeukemiaNet. Leukemia 2018;32 1057-1069.

37. Mesa RA, Jamieson C, Bhatia R, et al. NCCN Guidelines Insights: Myeloproliferative Neoplasms, Version 2.2018. J Natl Compr Canc Netw 2017;15:1193-1207. 